\title{
A SEDIMENTOLOGICAL CONTINUUM OCCURRING THROUGH GEOLOGIC TIME: A STUDY FOR STUDENTS
}

B.R. PELLETIER

Geological Survey of Canada, 601 Booth street, Ottawa, Ontario, CANADA, K1A OE8

Exponential decrease in grain size with linear distance of sediment transport is expressed as a variation of Sternberg's Law. This variation is $Y=Y_{0} e^{-a x}$ in which $Y_{O}$ is the initial diameter of a particle, $\underline{Y}$ is the diameter of the particle after traveliing a distance $x$, and $a$ is the slope of the curve. This slope was designated the coefficient of size reduction by Stemberg. Determination of paleoslope attitude, and paleocurrent direction, and sedimentary anisotropy were achieved from the field measurements on vectoral properties of foreset beds and current ripples, and from the exumination of sedimentologic-stratigraphic maps such as grain size distribution, isopachs, and facies.

The basice equation $\left(Y=Y_{0} e^{-\alpha x}\right)$ is applied to grain diameters of sediment samples from Arctic rivers, thus representing sedimentation on the moderm temporal plane. Next, the mathematical operations carried out on both scalar and vectoral entities are applied to the upper and lower parts of a Silurian member (the Grimsby Sandstone in the Niagara Peninsulal of Ontario, in order to illustrate the persistence of the exponential law through a small interval of geologic time. Superposition of the size-distance curves representing top and bottom beds show parallelism of slope. The operations applied across two members (the Grimsby and overlying Thorold sandstonel show a similar parallelism of size-distance curves. The operations applied across several formations representing almost con entire geologic period (the Triassic sandstones of northeastem British Columbia - Toad, Liard, and. Grey Beds) yield a family of negative, exponential, size-distance curves, drown from the textural analyses. Finally, the operations are applied to formations representing a long interval of geologic time (the conglomerates of the Lower Mississippian Pocono and lower Pennsylvanian Pottsvilie). Sizedistance curves based on textural variations along a scompling line trending northwesterly across Pennsylvania were constmucted and superposed on the same graph. The resulting relationship demonstrates that under prograding conditions a natural law of growth for sedimentary clastic bodies exists and persists over long periods, being expressed in the form of a fomily of negative exponential curves. Also, this low together with sedimentary anisotropy and progradation constitute a sedimentologic continum operating through this different but successive interval of geologic time.

\section{INTRODUCTION}

Fundamental work on the concept of grain-size decrease during sediment transport was carried out by Sternberg (1875), when he noted a decrease in the grain diameter of sediments carried by the Rhine River, Germany. He related this phenomenon to the changing weight of the particles and, much later, Barrell (1925) formalized this concept in the expression now called Sternberg's law: $W=W_{0} e^{-a x}$ in which $\underline{W}$ is the weight of the particle after travelling over a distance $x_{\text {, Wo }}$ is the initial weight of the particle, and a is the coefficient of size reduction. In the $1 \overline{9} 50$ 's Pettijohn (1975) suggested that, for studies on gravels, diameters of pebbles be used in place of weight so that the new expression became: $\mathrm{Y}=\mathrm{Y}_{\mathrm{O}} \mathrm{e}^{-\mathrm{ax}}$ in which $\mathrm{Y}$ is the diameter of the pebble. Pettijohn also suggested measuring the largest diameter of the 10 largest pebbles, rather than utilizing the mean grain size of the entire sample population. This procedure was followed by Schlee (1956), Pelletier (1958), and Yeakel (1962). All workers confirmed the earlier results of sternberg; sediments decrease in size in a down-current direction. Work on modern fluvial deposits by Plumley (1948) had indicated that such a size decrease depended upon the occurrence of a gradient in the stream bed.
Although size-distance curves of sediment particles may give an indication of the distance of sediment transport, they fail to define the paleoslope uniquely. This can be accomplished by mapping mean grain size of deposits at several localities, and contouring the data in the form of isopleths. The mathematical surface thus generated will be representative of the paleoslope. An orthogonal drawn across the isopleths will represent the regional direction of sediment transport. This orthogonal is used in a vectoral sense because it crosses the map from high scalar values to lower ones, and thus has a preferred direction. If all such orthogonals for a given paleoslope are given a magnitude of unity for the purpose of obtaining a vectoral mean, then the isopleth map respresenting these paleoslopes has an inherent vectoral quality.

vectoral properties have been assigned directly to sedimentary structures for the purpose of deducing routes of sediment transport. Historically the foremost worker in this field was Sorby (1859) who noted that foreset bedding and migrating current ripples could be utilized in deducing ancient routes of sediment transport. The down-current direction indicated by these structures can be represented by an arrow and, by giving the value of unity to each arrow, a vectoral summation can be made in order to determine regional paleocurrent directions. Thus, sedimentary anisotropy and paleocurrents can be 
Many modern workers have applied these principles (see Pettijohn 1975). For the purpose of this study it is not essential to review all paleocurrent indicators, but it is important to examine their relationship to sedimentary anisotropy. In this relationship, these primary sedimentary structures indicate a preferred direction of sediment accumulation in the direction of sediment transport. Therefore, sedimentary anisotropy is demonstrated, and deductions based on the application of Sternberg's Law are an intimate part of this phenomenon.

With the use of such basic tools as a scale and Brunton compass (or similar alternatives) applied to sediment particles and structures, it is possible to determine anisotropic growth in sedimentary bodies; but more importantly, these deductions can be drawn from an examination of successive sedimentary accumulations that are deposited under prograding conditions. It is in this context that Sternberg's Law and sedimentary anisotropy occur as a continuum through geologic time.

In the present study, this sedimentological continuum will be examined first on the modern temporal plane. This is the smallest geological time unit; also, for this exercise, the direction of sediment transport is known. Next, the study will show sedimentary anisotropy produced during the geological time interval required for the deposition of a single member. Because it is the purpose of the present study to examine Sternberg's Law and sedimentary anisotropy under prograding conditions, the immediately overlying member will also be analyzed. The third part of the study will deal with sedimentary anisotropy produced during the deposition of a formation. Three successively overlying formations will be included in order to demonstrate the sedimentological continuum existing over the larger time span of nearly an entire geological period. The final analysis demonstrates Sternberg's Law and sedimentary anisotropy in two major formations occurring in separate, but successive periods. They also were deposited under similar, prograding conditions. In this case, such sedimentation occurring in a significant portion of a geological era is exemplified. Throughout this study, attention will be given to fluvial, sub-aerial deltatic, and nearshore marine environments.

\section{DEPOSITION FOR A GIVEN TEMPORAL PLANE}

For the purpose of this study, sedimentary processes taking place in modern streams have been selected. Almost all streams originating in highland areas contain deposits with properties that characterize both the sedimentary processes and the distance of sediment transport. The alteration of these properties occur as changes in shape, angularity, and mean grain size (Figs. 1-3). Certain structures are also apparent, such as crossbedding and ripple marking along parts, if not all of the river course (Fig. 4). At the point where rivers enter the sea, extremely vigorous hydrodynamic conditions may prevail so that large-scale sand waves that exhibit alternating anisotropy may form (e.g. Bay of Fundy, Nova Scotia, Fig. 5, see Swift et al 1973, Knight 1977). In cases where

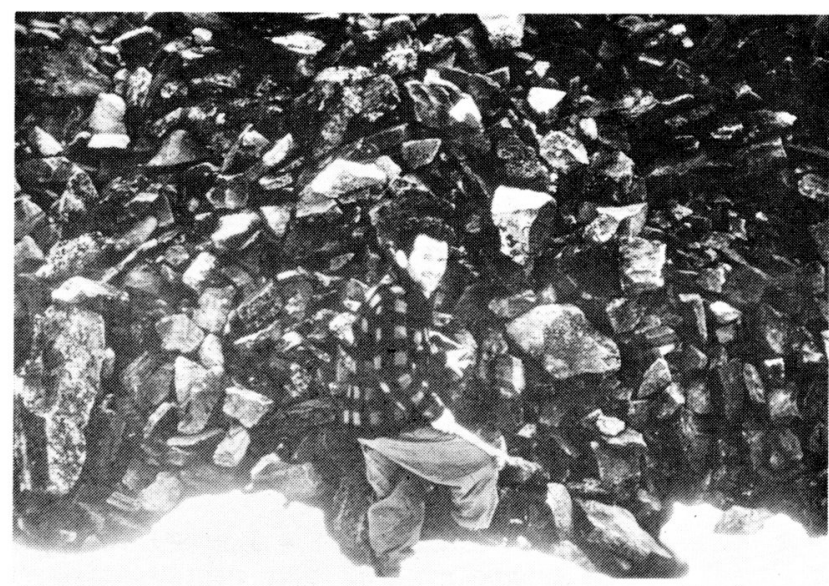

FIG. 1 Large, mechanically derived blocks of bedrock at a mountain watershed, Yukon Territory. The starting point of the processes leading to sedimentary anisotropy and grain-size decrease. Large blocks here are $350-500 \mathrm{~mm}$ across.

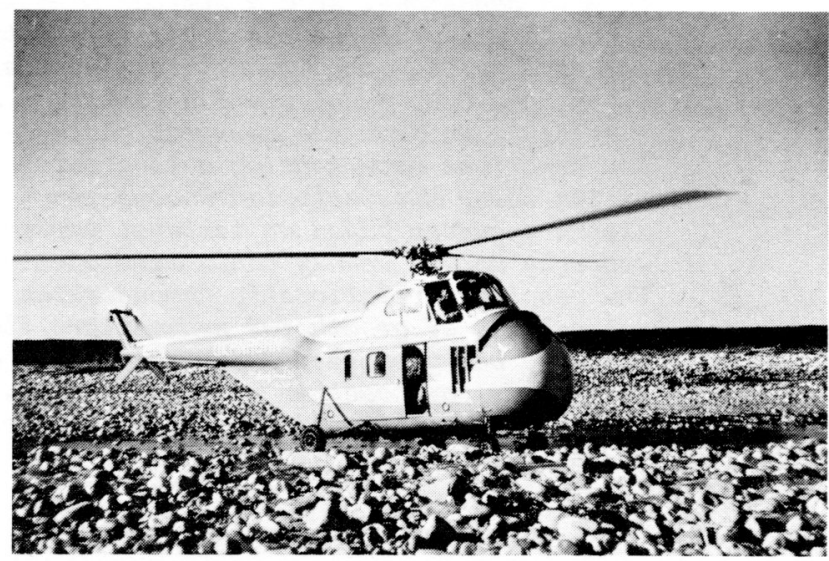

FIG. 2 Well rounded cobbles occurring at the fall line of mountain rivers, Yukon Territory. Mean diameter of cobbles is about $150 \mathrm{~mm}$. Decrease in grain size is already apparent.

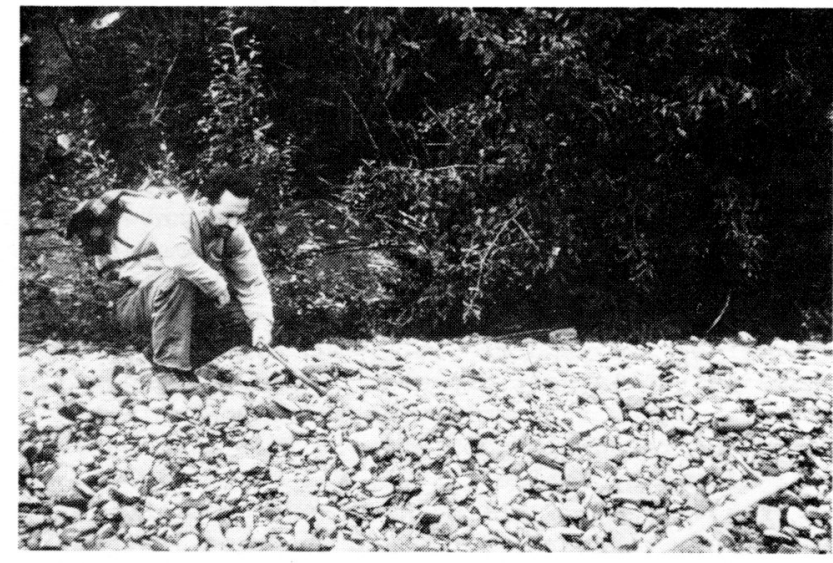

FIG. 3 Well sorted, imbricated river gravels occuring a few miles downstream from a fall line in northeastern British Columbia. Mean diameter of cobbles is about $100 \mathrm{~mm}$. Hand-held hammer is parallel with fabric direction; this fabric is an example of sedimentary anisotropy. 


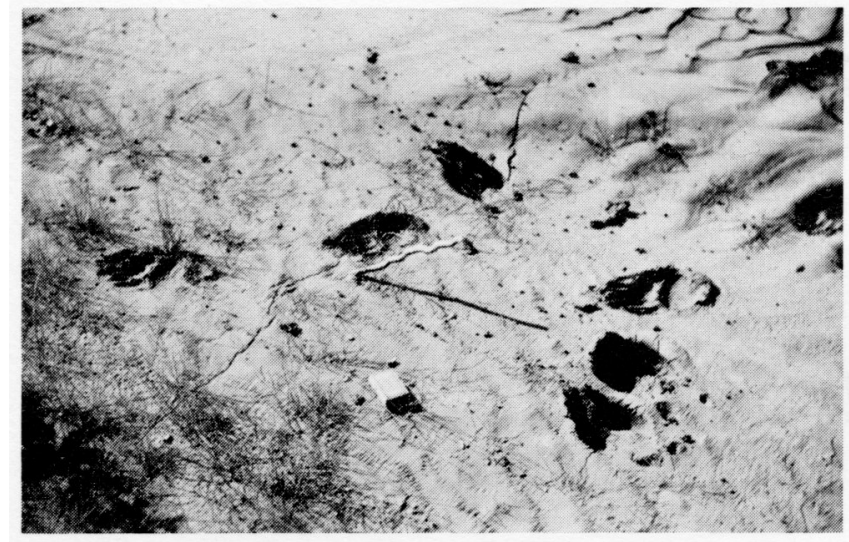

FIG. 4 Well sorted sands occurring in mid-reach of river, but many miles downstream from fall line. Site is near confluence of main trunk. Silts are also present. Asymmetric ripple marks indicate flow from left to right in photograph, thus demonstrating sedimentary anisotropy. Animal tracks and plant remains indicate depositional environment.

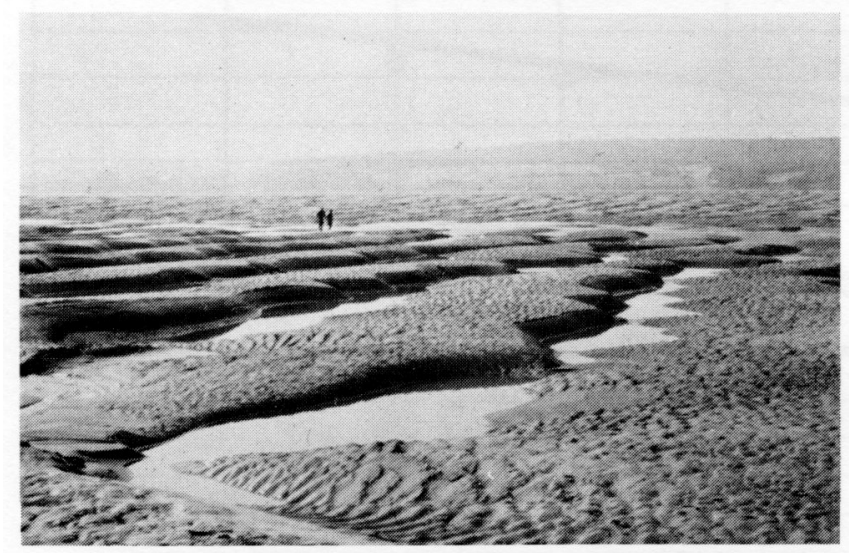

FIG. 5 Large-scale ripples and sand waves in a high energy, intra-tidal environment of the Bay of Fundy, Nova Scotia. Currents flowed from left to right in the photograph but as this site is intertidal, some primary structures in cross-section show reverse flow.

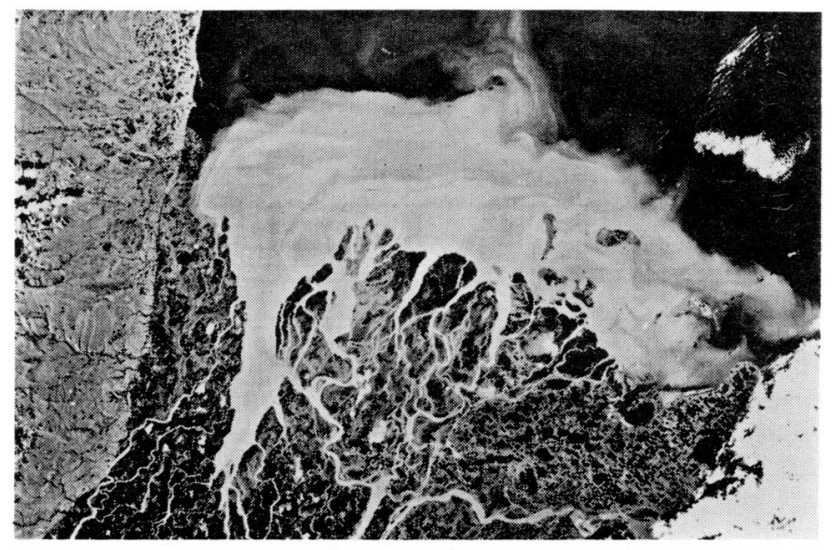

FIG. 6 Sediment plume of Mackenzie River discharge into Beaufort Sea. Plume comprises silt and clay with only $2 \%$ sand in bed load. No sand waves present due to low hydrodynamic vigour and small tidal range (less than $0.5 \mathrm{~m}$ ). rivers discharge into a relatively less vigorous hydrodynamic environment, primary sedimentary structures may not form so that normal flocculation and sediment dispersal may take place (e.g. Beaufort Sea, Yukon Territory, Fig. 6, Pelletier 1975, 1979). In either case sedimentary anisotropy developed under fluvial conditions may not be continuous with those developed in the coastal, deltaic, or estuarine environment.

To demonstrate sedimentary anisotropy from the analysis of scalar properties of fluvial sediments occurring on a given temporal plane, several short-length rivers occurring in the Canadian Arctic Archipelago have been chosen and sampled. These rivers (Fig. 7) are not major streams such as the Nile, Amazon, or Mackenzie, but they are complete fluvial systems in that they have a full course from their highland source to their shoreline terminus. Also they occur in an area of active relative uplift (Pelletier 1966, 1967), so that a stream-bed gradient exists concommitantly with prograding conditions.

In the first study of these stream deposits, the data of Table 1 indicates a decrease in mean grain diameter, sand, and heavy mineral content in the down-stream direction. The size-frequency distribution of the sediment population also changes from a bimodal character in the highlands, to a unimodal one in the lower reaches of the river. This, in itself, is a demonstration of sedimentary anisotropy that is observable in statistical moments. At the shoreline, a perceptible increase is evident in the median diameter, sand fraction, and heavy mineral content of the sediment. This is due to the winnowing action of the waves during ice-free periods along a coast characterized by a low tidal range. In the adjacent nearshore marine environment, the sediment properties resume their trends towards decreasing grain size, sand content, and heavy mineral content. The processes attributed to the development of sedimentary anisotropy are active in this zone.

When the median diameters of the river samples are plotted on a semi-logarithmic graph (Fig. 8) the sample points fall on, or lie close to a straight line. This operation demonstrates the principle of exponential decrease in grain size with linear distance of transport. Only the mean grain diameter of the sample from the highest portion of the river bed fails to lie on this line. This may be a result of bimodality in the size-frequency distribution of the sample.

In order to test this possible bimodal effect on the size-distance curve, three additional rivers were sampled from headwaters to mouths. The mean grain size of each sample was plotted on a semilogarithmic base (Fig. 9, see Pelletier 1967). The results were similar to those of the first river (Fig. 8 ), in that all values fall on a straight line except those for the highland samples. In fact, those values in the case of River 3 (Fig.9) actually fall on a separate straight line. This line is parallel to the size-distance graph for the lowerriver samples and, as such, represents a family of curves.

The gravel portions of these highland riverbed samples were separated, and the mean grain size of the remaining portion of the samples was determined and plotted in the same graph. All such points for their respective curves coincide with the projection 


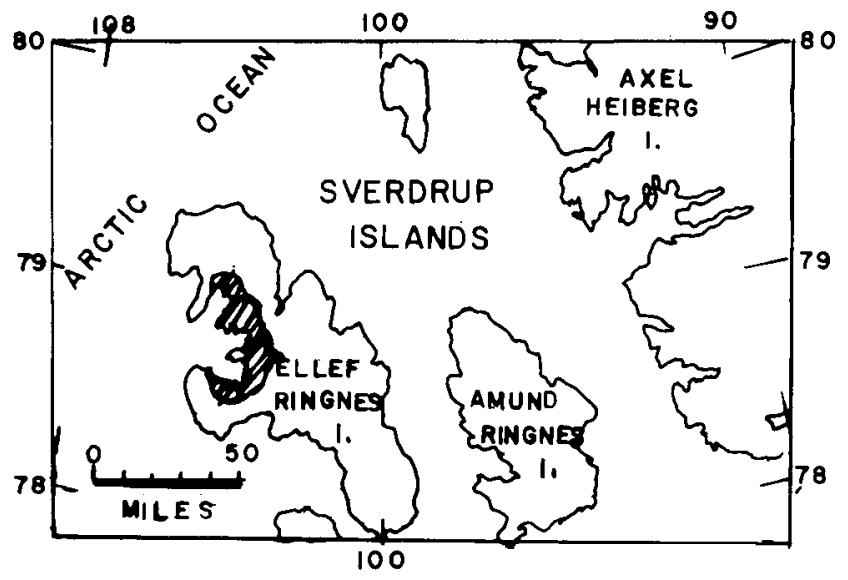

FIG. 7 Location of Arctic rivers, Ellef Ringnes Island, District of Franklin. Shaded area indicates terrane over which rivers flowed, and is less than $\mathbf{2 0 0} \mathrm{m}$ elevation.

\section{$\gamma$}

FIG. 8 Size-distance curve demonstrating the exponential decrease in grain size of sediments in an Arctic river undergoing fluvial transport from headwaters to the sea (see Table 1).
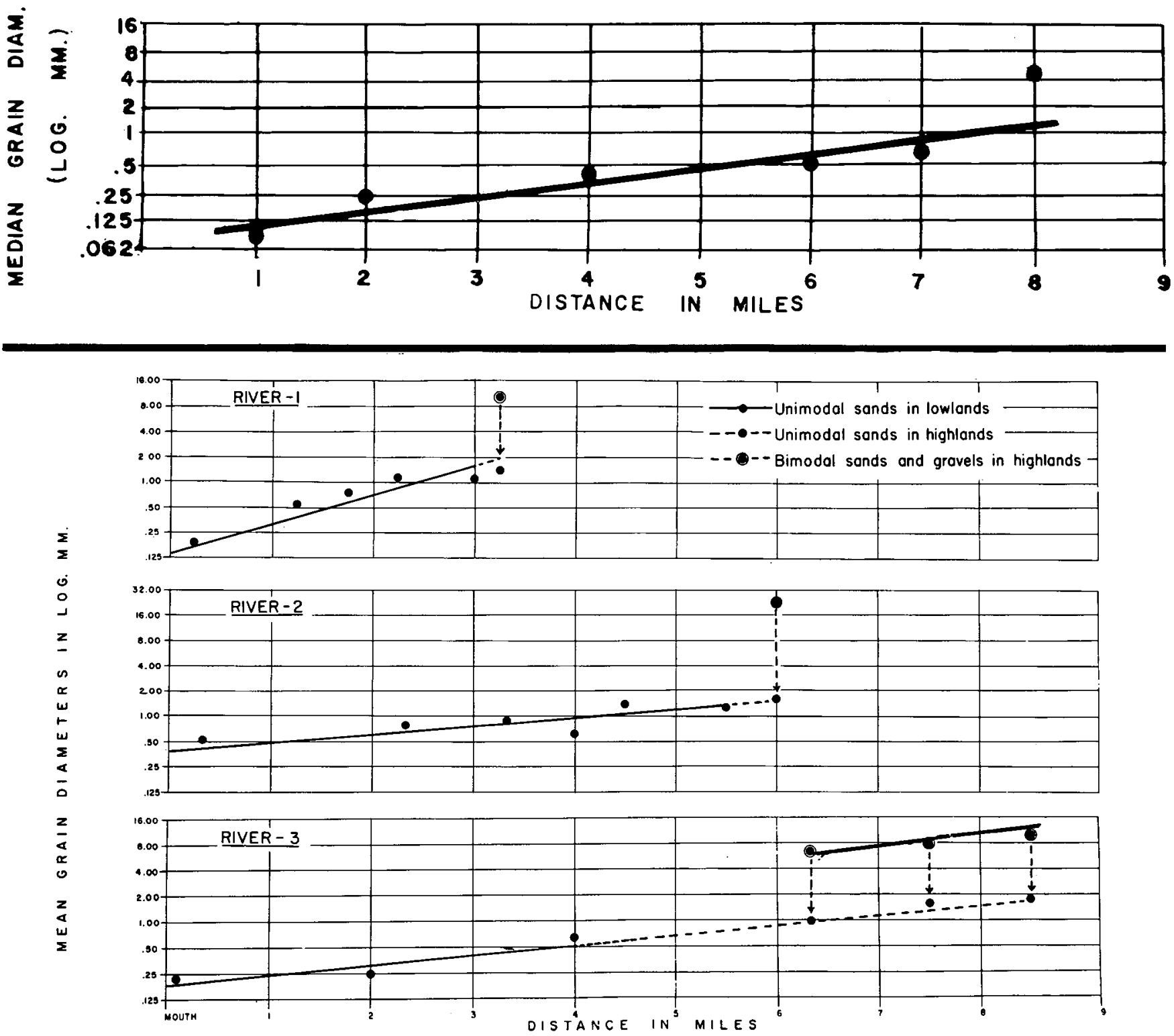

FIG. 9 Size-distance curves demonstrating the exponential decrease in grain size of sediments in three additional Arctic rivers. Sediments were obtained at sites from headwaters to river mouths. Note family of curves in panel for River 3. 
TABLE 1

Variation in grain size, sand fraction, and heavy mineral content in Arctic fluvial sediments

\begin{tabular}{|c|c|c|c|c|}
\hline $\begin{array}{l}\text { Fluvial } \\
\text { Environment }\end{array}$ & $\begin{array}{l}\text { Distance } \\
\text { From Shore }\end{array}$ & $\begin{array}{l}\text { Median Grain } \\
\text { Diameters (mm) }\end{array}$ & $\begin{array}{l}\text { Sand } \\
\text { Fraction ( } 8)\end{array}$ & $\begin{array}{l}\text { Heavy } \\
\text { Minerals (o) }\end{array}$ \\
\hline \multirow{3}{*}{$\begin{array}{l}\text { Highland } \\
\text { area }\end{array}$} & 8 miles & 5.50 & 96 & 1.90 \\
\hline & 7 & 0.70 & 94 & 0.90 \\
\hline & 6 & 0.58 & 90 & 0.87 \\
\hline \multirow{3}{*}{$\begin{array}{l}\text { Lowland } \\
\text { area }\end{array}$} & 4 & 0.34 & 83 & 0.54 \\
\hline & 2 & 0.18 & 71 & 0.32 \\
\hline & 1 & 0.09 & 35 & 0.64 \\
\hline Shoreline & & 0.38 & 74 & 1.51 \\
\hline \multirow{3}{*}{$\begin{array}{l}\text { Deltaic } \\
\text { marine }\end{array}$} & +200 feet & 0.03 & 9 & \\
\hline & +400 & 0.06 & 7 & \\
\hline & +800 & 0.03 & 4 & \\
\hline
\end{tabular}

of the size-distance curves of the unimodal samples. These curves demonstrate the law of exponential decrease in particle size with linear distance of sediment transport; that is, Sternberg's Law. The graphs clearly show the sedimentary anisotropy because the direction of stream flow is known and it coincides with the direction of decreasing grain size. But the most significant part of the analysis lies in the fact that the mean grain size of the separated gravel portions also are plotted on a straight line for their respective rivers (see River 3, Fig. 9). This demonstrates an exponential grain-size decrease with Iinear distance of transport. Moreover, both the gravel, and sand sizedistance curves are parallel, thus exhibiting the simplest representation of a family of curves of the general expression $\mathrm{Y}=\mathrm{Y}_{\mathrm{O}} \mathrm{e}^{-\mathrm{ax}}$. Therefore, this family of curves also demonstrates Sternberg's Law and the associated phenomenon of sedimentary anisotropy.

THE TIME PERIOD OF A GEOLOGIC AGE: THE GRIMSBY AND THOROLD SANDSTONES

For this portion of the study, the Grimsby and Thorold sandstone - two geological members occurring in the Silurian of the Niagara Peninsula of Ontario - are selected. Data are taken from reports by Pelletier (1953) and Lumsden and Pelletier (1969). These workders deduced that the sediments were deposited in a deltaic subaerial, to nearshore marine environment. From hand specimens of the sandstones collected at the outcrop, mechanical analyses on approximately 20000 grains were carried out on thin sections by means of a camera Iucida attachment on the petrographic microscope. Corrections for determining true grain diameters were calculated from the size-frequency distribution curves for each sample.

As the data in Table 2 indicates, the mean grain size of the lower Grimsby decreases from the southeasterly section at Niagara Falls, to the northwesterly one at Clappison. This decrease is exponential with linear distance of sediment transport, and is an example of Sternberg's Law. Paleocurrents flowed southwesterly as depicted in Figure 10 so that the direction of grain-size decrease coincides with sedimentary anisotropy. Although some increases along this trend occur locally, the size-distance curve (Fig. Il) represents the overall decrease fairly closely.

The same observations on grain-size decrease are similar for the upper part of the Grimsby (Table 2, and Fig. 11); both parts of this member show decreasing grain sizes in the direction of sediment transport. An approximate size-distance curve can be drawn (Fig. 11), which indicates a northwesterly decrease in mean grain size of this upper sandstone. However, an additional observation may be made for the grain size of the upper Grimsby; it is generally coarser than the lower part. Because this dual set of observations was made for the Grimsby at the same series of stratigraphic sections, it is concluded that prograding conditions of sedimentation for this member prevailed throughout Grimsby time. This prograding phenomenon is demonstrated in Figure 11 , which shows the superposition of the upper Grimsby size-distance curve over that of the lower Grimsby. Both graphs are 


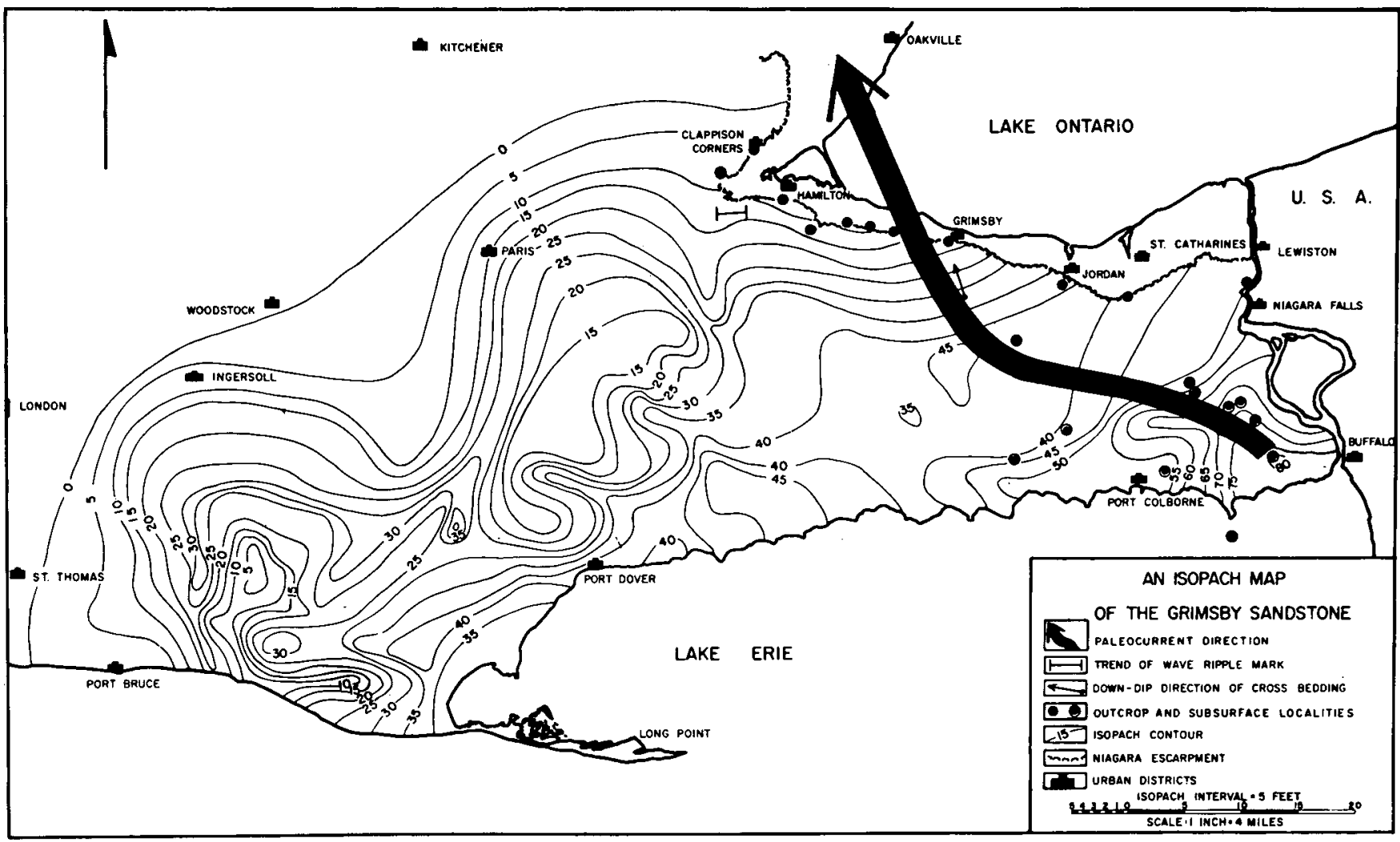

FIG. 10 Isopach map of the Grimsby Sandstone in the Niagara Peninsula, Ontario. Paleocurrents crossed arcuate trend of ancient delta. Sampling localities shown as dots.

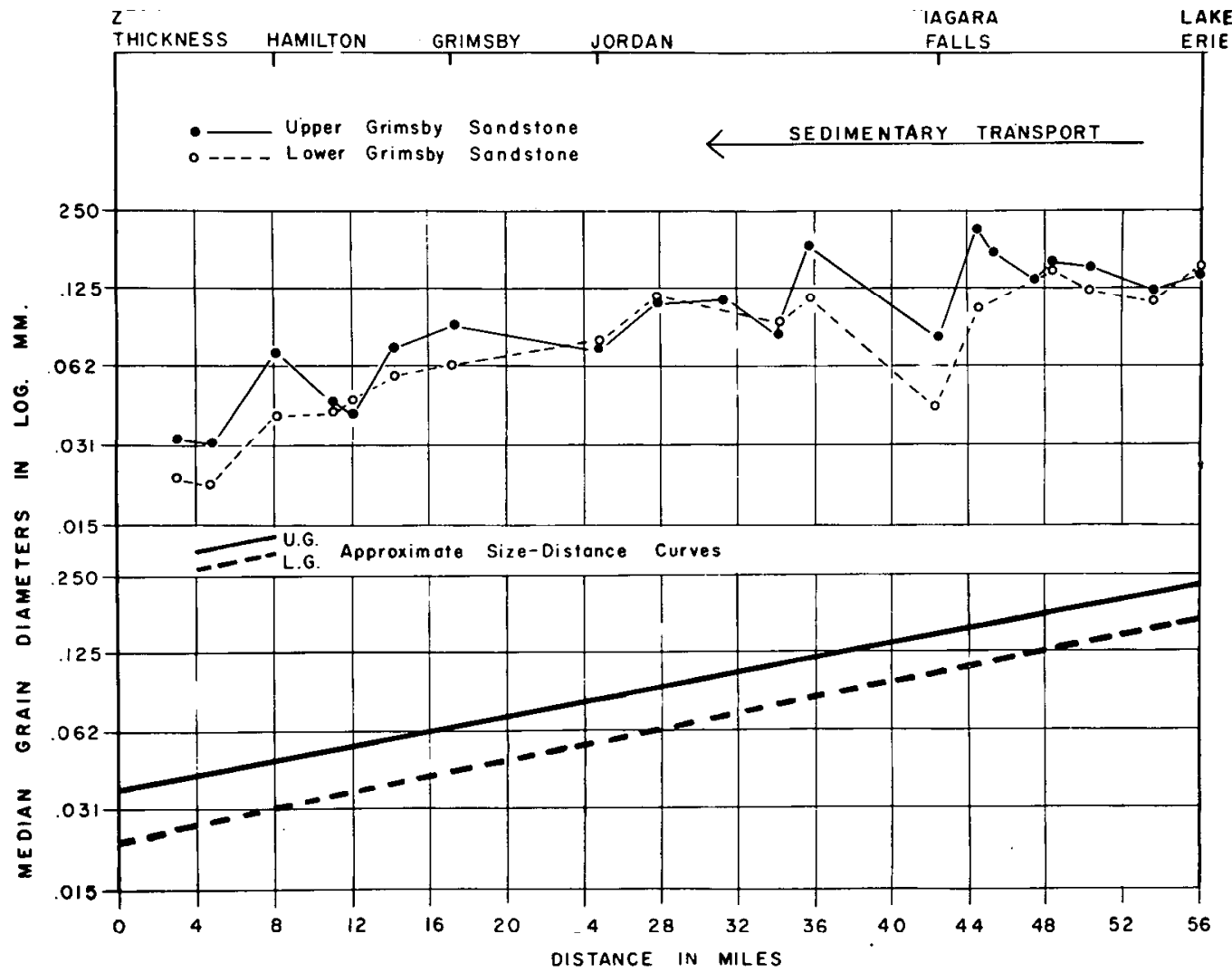

FIG. 11

Size-distance curves of the Grimsby Sandstone showing exponential decrease in grain size with linear distance of transport. Upper panel shows var" $a^{\prime}$ ion in $s^{\prime}$ ra $^{\prime} i-$ graphic sections along delta transect paralleling the paleocurrents. Lower panel shows approximate curves for both lower and upper parts of Grimsby, and their parallelism with each other. 
TABLE 2

Variation in mean grain size (mm) of the

Grimsby sandstone along the Niagara Escarpment

\begin{tabular}{|c|c|c|c|c|c|c|c|c|c|}
\hline & Clappison & Dundas & Hamilton & Albion & $\begin{array}{l}\text { Stoney } \\
\text { Creek }\end{array}$ & Vinemount & Grimsby & Jordan & $\begin{array}{l}\text { Niagara } \\
\text { Falls }\end{array}$ \\
\hline $\begin{array}{l}\text { Upper } \\
\text { Grimsby }\end{array}$ & .050 & .043 & .096 & .071 & .087 & .092 & .120 & .091 & .120 \\
\hline $\begin{array}{l}\text { Lower } \\
\text { Grimsby }\end{array}$ & .035 & .018 & .068 & .062 & .066 & .090 & .120 & .120 & .060 \\
\hline
\end{tabular}

Current Direction

Northwest

parallel and thus form a family of curves that expresses Sternberg's Law. Because this phenomenon represents deposition of the entire Grimsby, the sedimentological continuum involving Sternberg's Law and sedimentary anisotropy developed under prograding conditions through geologic time is demonstrated. The Thorold sandstone, overlying the Grimsby, was also examined at several localities in the Niagara Escarpment. This member is coarser than the Grimsby, and is thought to be the subaerial deltaic facies of the underlying lower siluarian beds. Several samples from the field sections were examined petrographically, and the grain size of each was measured. Values of the mean grain size for each locality were plotted on a semilogarithmic graph (Fig. 12), and an exponential decrease in mean grain size with linear distance of transport was observed. This trend parallels the presumed paleocurrent trend (similar to that of the Grimsby) in that the sand grains are coarser in the southeast at Niagara Falls, and, finer in the northwest near Hamilton. Thus, the direction of decreasing grain size and sedimentary anisotropy for the Thorold are coincident. Because this phenomenon was similar to that of Grimsby sedimentation, it appeared instructive to compare both the Thorold and underlying Grimsby.

The graphic plot for each of these members

(Fig. 12) shows an exponential decrease in mean grain size with linear distance of transport in a northwest: direction. This direction is also the direction of sedimentary anisotropy as determined from an analysis of cross-bedding, ripple marks, and regional stratigraphy (Pelletier 1953, Lumsden and Pelletier 1969). Most notable of the graphs in Figure 12, is the fact that they are parallel. This again demonstrates the simplest representation of a family of curves expressing sternberg's Law; it is similar to the case for the Arctic rivers, and for the synthesis of lower and upper Grimsby. Because the Thorold is coarser than the Grimsby and directly overlies that member, the phenomenon depicted is one of a prograding sedimentary regime. This finding demonstrates the sedimentologic continuum of Sternberg's Law and sedimentary anisotropy over two geological ages.

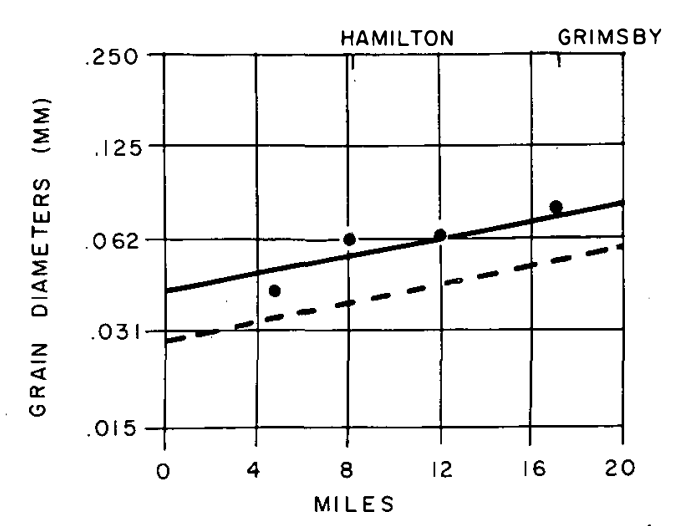

FIG. 12 Approximate size-distance curves for the Grimsby and Thorold sandstones. The exponential decrease in grain size in the direction of transport is apparent, as is the parallelism of the curves with each other.

THE TIME INTERVAL OF A GEOLOGIC PERIOD: THE TRIASSIC OF NORTHEASTERN BRITISH COLUMBIA

In this portion of the study, sedimentation taking place through most of a geologic period is examined. The units under study are the sandstones of three Triassic formations of northeastern British Columbia - the Toad, Liard, and Grey Beds. For the purpose of this paper and easier reference to earlier work (Pelletier 1962), the original provisional names are used. Seventy sections were measured and a stratigraphic correlation table was constructed. This correlation indicates that a source area lay to the northeast and east of the Rocky Mountain Foothills of northeastern British Columbia, that uplift occurred in the source area as indicated by the presence of an unconformity, and that progressively younger beds appear stratigraphically higher in the sections to the west. This was an early indication of prograding conditions occurring throughout most of Triassic times.

In the field, about 2500 paleocurrent observations were made on cross-bedding, current ripples, wave ripples, festoon beds, and sole markings. From these studies it was inferred that the paleocurrents 


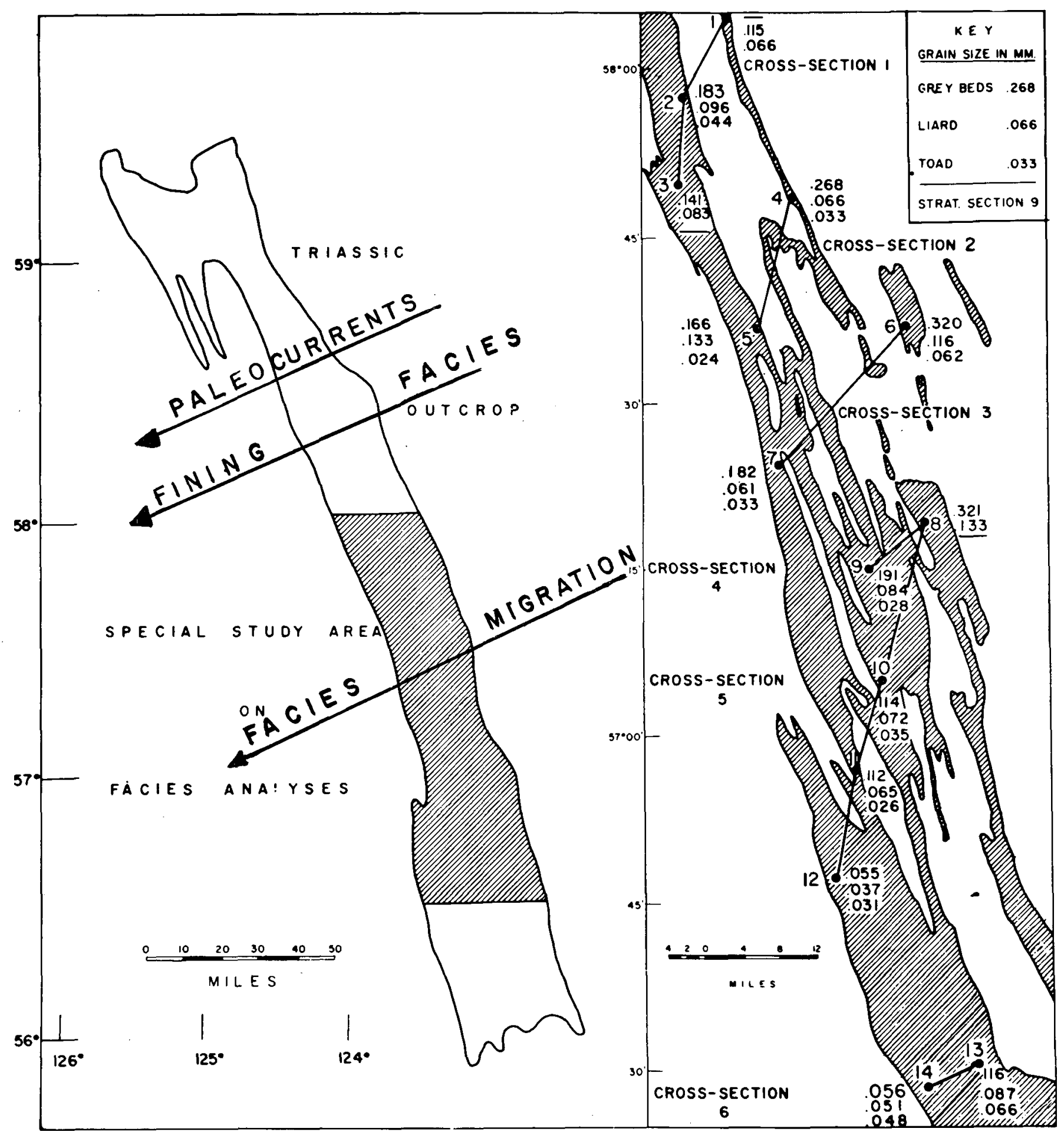

FIG. 13 Triassic Paleocurrents. Left panel shows outcrop area of Triassic rocks in northeastern British Columbla. Paleocurrents inferred from analyses of cross-bedding, festoon bedding, current ripples, grain-size decrease, and facies shift. Right panel shows outcrop area sampled for textural and facies study (see shaded portion in left panel). Six cross-sections were made on examination of 14 stratigraphic sections. Grain-size decrease to southwest is apparent, as is progradation. 
flowed westerly and southwesterly toward the basin of deposition. The paleocurrent direction coincided with the direction of the paleoslope inferred earlier from the stratigraphic analysis (Fig. 13).

About 250 hand specimens were collected from outcrops of the three Triassic units studied. The hand specimens were examined under the binocular microscope, and the mean grain size of each was determined with the aid of a grain-size comparator. Locality averages of the mean grain size for each formation were plotted on a map of the area (Fig. 13), and then projected onto two respective transects (one for the north, and one for the south) directed across the sedimentary strike and, thus, parallel with the dip of the paleoslope. As inferred above this direction is that of the paleocurrents and, hence, sedimentary anistropy. The two transects were used to draw the sizedistance graphs for the grain-size trends for each of the three formations: one transect represented sedimentation in the northern part of the study area, and the second transect similarly represented the southern area. All data were plotted on a semi-logarithmic base which clearly showed an exponential decrease in mean grain size with linear distance of transport. Thus each formation in each set of graphs demonstrated Sternberg's Law. Because the mean grain sizes are coarser in the east and northeast, and decrease toward the west and southwest, the direction of decreasing grain size is parallel with the sedimentary anisotropy.

The size-distance graphs also show that the average grain size of the younger sandstone formation is always coarser than that of the directly underlying older ones. For example, sandstones of the Grey Beds are coarser than the older, underlying sandstones of the Liard which, in turn, are coarser than the yet older sandstones of the Toad. This relationship holds for all units comprising the stratigraphic sections used in this analysis, and its origin is due to sedimentation under prograding conditions.

Another significant observation can be made from these size-distance curves in Figure 14: the three graphs in each set are parallel to sub-parallel in slope, and thus represent a family of curves. These curves are an expression of sternberg's Law. They show slight divergence from a common slope, which may be due to a difference in the amount of uplift in the source area. With increased uplift, topographic gradients would be steeper and prograding sedimentation would be induced or intensified. Prolong erosion and subsequent lowering of the topographic gradient would lead to less vigorous prograding sedimentation. This would be reflected in a size-distance curve with a gentler slope because mean grain sizes in the deposits near the source would be finer. These considerations are implicit in any account of sedimentary tectonics. However, the nearparallelism of these graphs, which slope in the direction of sediment transport, indicates the following: the sedimentological continuum of Sternberg's Law, sedimentary anisotropy, and sedimentation under prograding conditions occurs throughout most of a geologic period.

An analysis was also carried out on the variation in thickness of cross-bedded units in the Liard and the Grey Beds. The average thickness

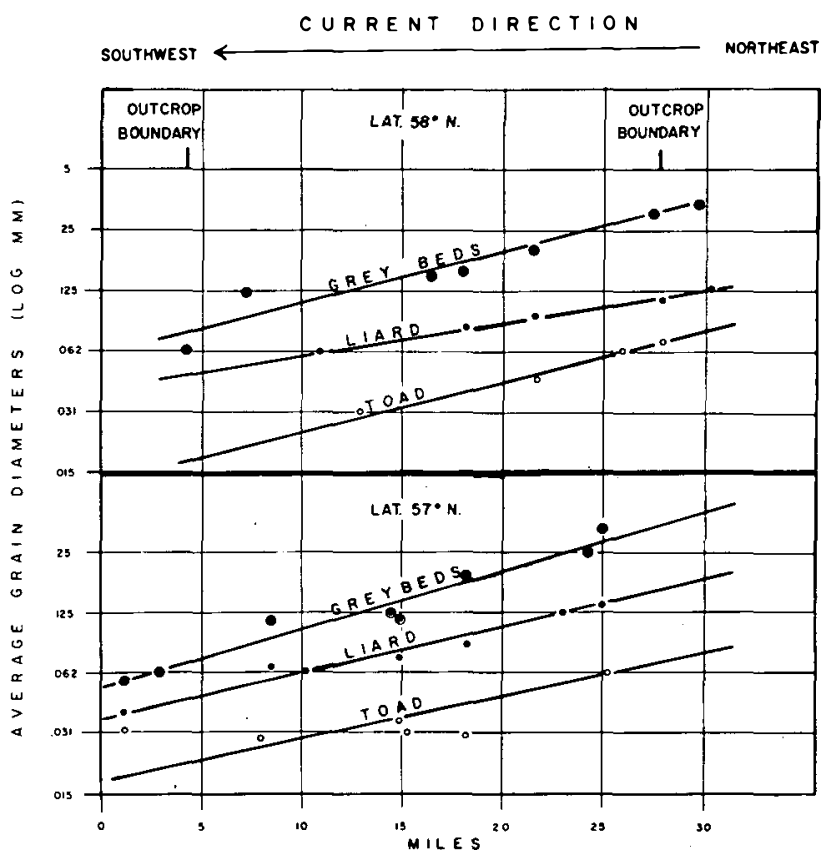

FIG. 14 Size-distance curves of Triassic sandstones in northeastern British. Columbia. Exponential decrease in grain size to southwest, with linear distance of transport, is demonstrated. Family of curves is shown for both the northern and southern area of the outcrop belt.

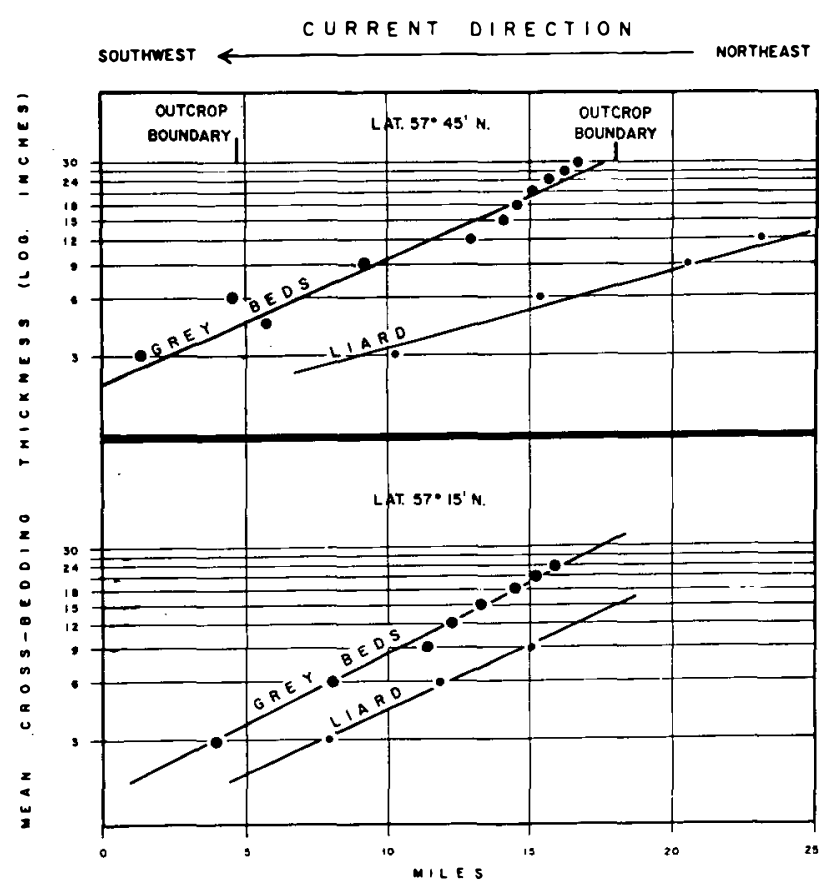

FIG. 15 Thickness-distance curves of Triassic cross-bedded units occurring in northeastern British Columbia. Exponential decrease in thickness of these units, with linear distance of travel is shown, as is the prograding nature of the deposits. A parallelism of curves is apparent. 
of each formation was calculated from field measurements for several localities. These data were then projected onto the respective transects of the northern and southern parts of the areas, and then plotted on a semi-logarithmic, size-distance graph representing the transects (Fig. 15). The resulting graphs are similar to those drawn for the mean grain sizes (Fig. 14). Remarkably the dispersion of the data shows an exponential decrease in the thickness of cross-bedded units with linear distance, as measured from one locality to the next.

The direction of decreasing thickness is toward the southwest which coincides with the paleocurrent direction and sedimentary anisotropy. Similarily, as in the case of the size-distance curves for the grain-size of analyses, the graphs are parallel to sub-parallel and the younger coarser beds always overlie the older finer beds. Not only are these curves and their superpositioning another indication of prograding sedimentation and sedimentary anisotropy, but they represent another application of sternberg's Law. In this case the expression is $T=T_{0} e^{-a x}$ in which To is original cross-bedding thickness, and $x$ is the distance of sediment transport from $T$ to $\overline{\mathrm{T}}_{\mathrm{O}}$. Thus another factor is available in expressing the sedimentological continuum of Sternberg's Law, sedimentary anisotropy, and prograding conditions operating through a long period of geologic time.

\section{THE TIME INTERVAL OF TWO OR MORE GEOLOGICAL PERIODS: PART OF AN ERA}

This final section of the paper deals with the grain size and paleocurrent analyses of sediments deposited under prograding conditions occurring during the middle part of the Paleozoic Era in the central Appalachians. To establish the direction of the paleoslope, 6000 primary sedimentary structures were examined in the Upper Devonian rocks, the Pocono and Mauch Chunk Formations of the Mississippian Period, and the Pottsville conglomerate of the Lower Pennsylvanian Period.

The results on the overall cross-bedding study are shown in Figure 16, which also reveals the consistency in paleocurrent direction over such a long period of geologic time. Other indicators such as current ripples also support this interpretation on sedimentary anisotropy. For the Pocono study, additional indicators of paleocurrent directions were observed and include: wave ripples, oriented plant stems, and parting lineation in the sandstones. An interpretation of the regional stratigraphy of the Pocono, including the locating of terrestrial and marine fossils and the contruction of an isopach map, also provided a good paleogeographic model as a reference for this part of the study. Thus, the major elements in establishing sedimentary anisotropy over this major interval of geologic time were assembled. (Fig. 17, Appendix). Size analyses were carried out on the quartz pebbles of the conglomeratic beds, and this was performed at the outcrop. The largest diameter of several dozens of pebbles that were exposed at each outcrop visited, were measured in order to determine the ten largest pebbles for that locality. Then, the average of these ten largest diameters was calculated and directly assigned as the maximum pebble diameter for that locality. This value was plotted for each locality, and a pebble-size isopleth map

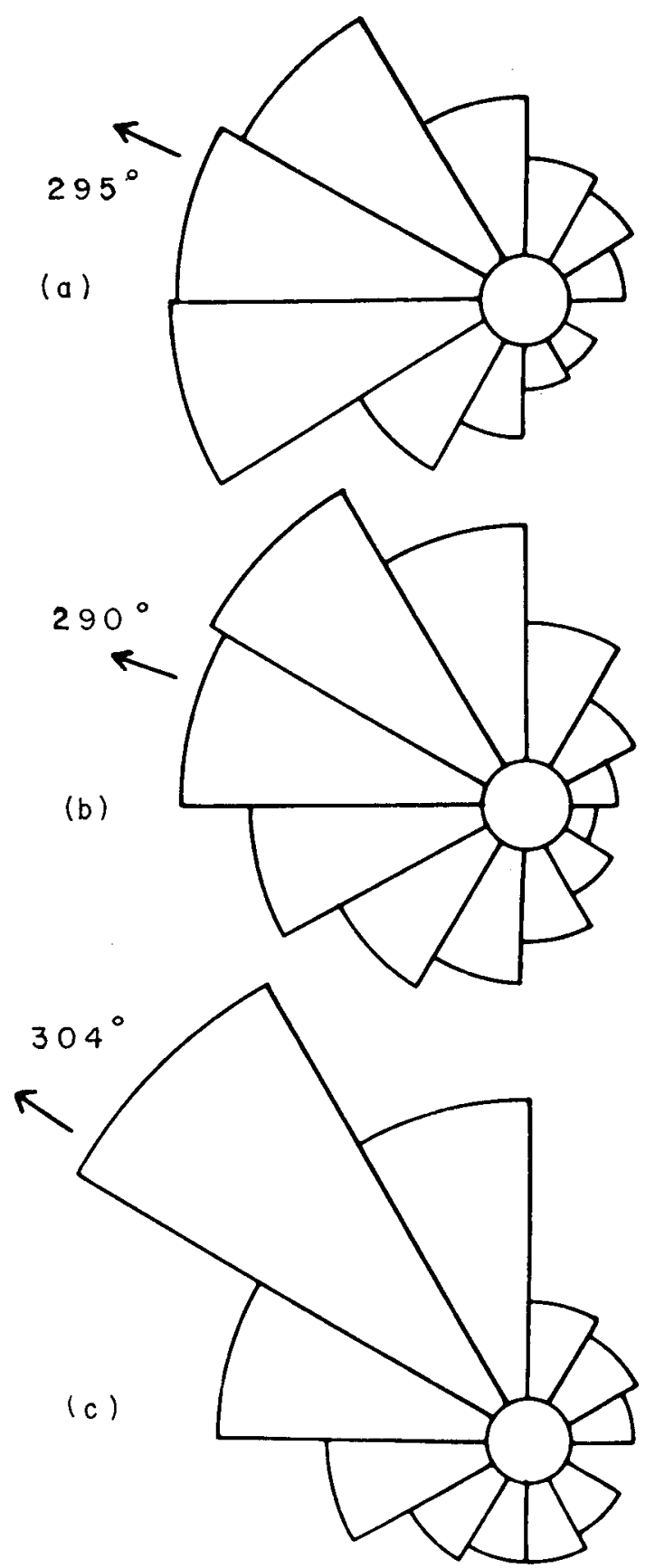

FIG. 16 Variation of current directions in late Paleozoic times. Mean current direction is based on dip direction of cross-bedding foresets, as shown by arrows: (a) Mauch Chunk; Upper Mississippian and Pottsville, Lower Pennsylvanian; 12 localities; 181 observations. (b) Pocono; Lower Mississippian; 227 localities; 4968 observations. (c) Upper Devonian sandstones; 3 localities; 94 observations. 


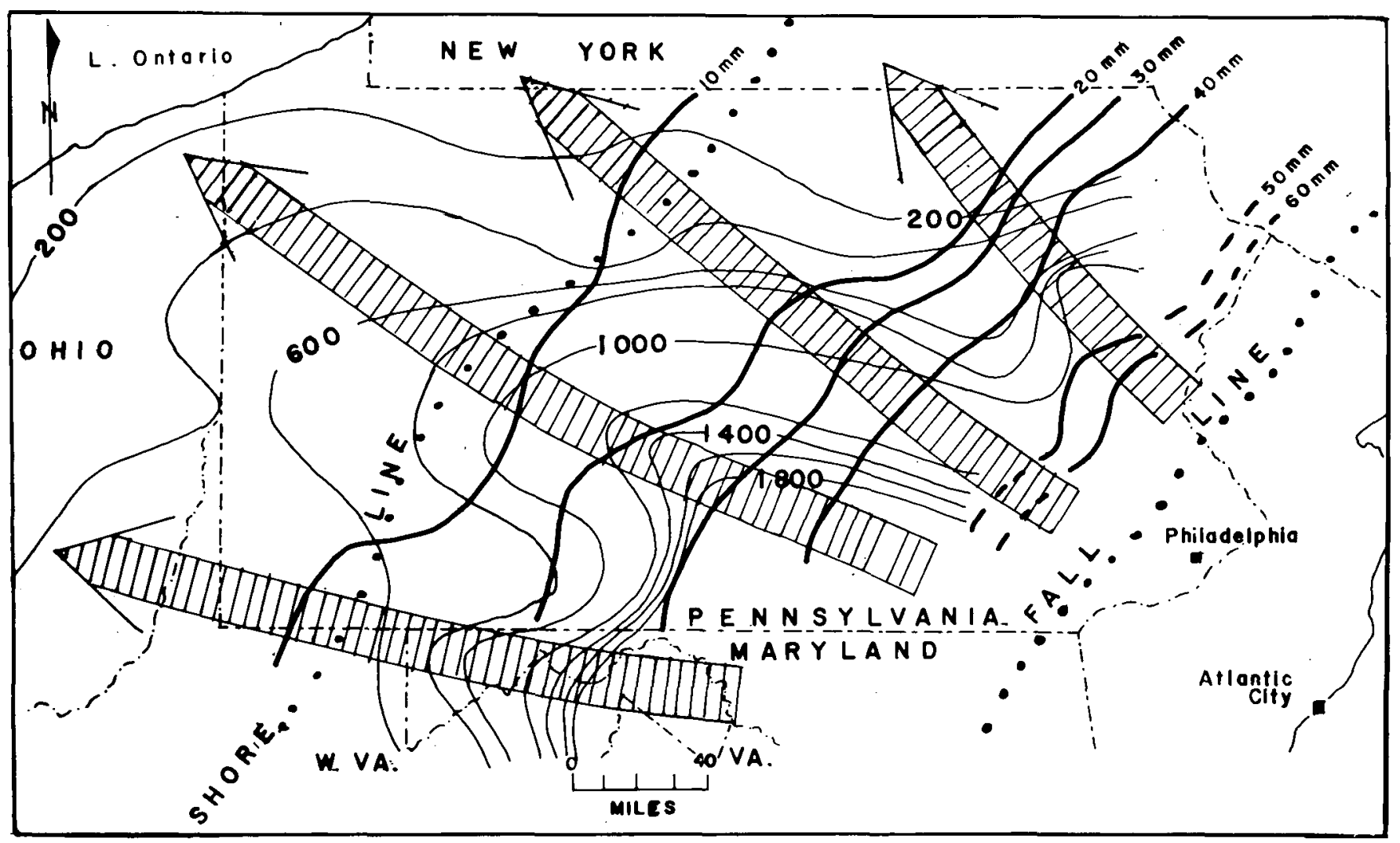

FIG. 17 Pocono Paleocurrents in the central Appalachians. Paleocurrents are directed across the arcuate pattern of the isopachs and isopleths of the pebble sizes, toward the northwest, and are based primarily on observations of cross-bedding, current ripples, and regional stratigraphy.

\section{APPROXIMATE SIZE-DISTANCE CURVES :}

$\bullet$

O - - - POCONO FORMATION

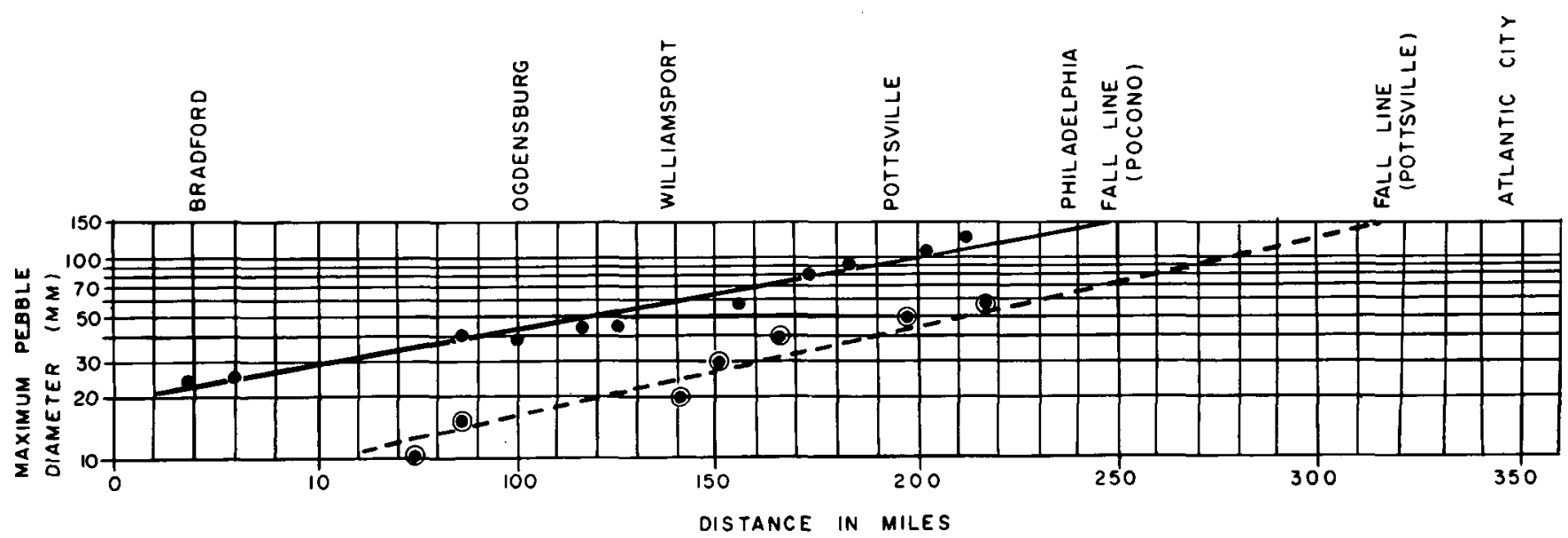

FIG. 18 Size-distance curves of the Pocono and Pottsville conglomerate, Pennsylvania. Size data on pebbles at outcrop were projected onto a line extending northwesterly from Philadelphia, toward southeastern New York State. Pebbles decrease in size in paleocurrent direction toward the northwest. Drawing shows prograding aspect of younger Pottsville conglomerates over older, underlying Pocono beds. 
was drawn which gave a clear indication of the paleoslope. Considering that pebbles decrease in a down-current direction with distance of sediment transport, then the paleoslope so constructed dipped northwesterly and westerly from a southeastern highland source. This interpretation is in accordance with the paleoslope model developed by means of paleocurrent and stratigraphic analyses (Fig. 17).

A similar but less extensive pebble-size analysis was carried out on the quartz pebbles of the Pottsville conglomerate. The paleocurrent analysis gave similar results as the Pocono study, which is not surprising because the paleoslope direction had been consistently westerly since Devonian times at least. But the most interesting phenomena revealed in this study emerged when the average of the maximum diameters of the 10 largest quartz pebbles occurring in both the Pocono and Pottsville were plotted as two curves on the same semi-logarithmic graph (Fig. 18). Both curves show an exponential decrease in pebble size with linear distance, in a northwesterly direction. This direction parallels that of the paleoslope, and coincides with the direction of sediment transport and therefore is a manifestation of sedimentary anisotropy. Not only does Sternberg's Law (i.e. $\mathrm{Y}=\mathrm{Y}_{\mathrm{O}} \mathrm{e}^{-\mathrm{ax}}$ ) apply to each curve, but both curves have similar slopes and thus represent a family of curves. Because the size-distance curve for the Pottsville conglomerate is only slightly steeper than that for the Pocono, it is inferred that uplift continued throughout this time period with slightly more intensity during Pottsville sedimentation.

Finally, the size-distance curves of the Pocono and Pottsville pebbles demonstrate that the graph for the younger Pottsville conglomerate consistently lies above that for the older Pocono beds. At each locality the Pottsville is coarser than the Pocono, that is, its pebblès are larger. This phenomenon demonstrates that similar sedimentary anisotropy had developed under prograding conditions. These conditions, together with the application of Sternberg's Law and the development of sedimentary anisotropy, constitute a sedimentologic continuum that persisted for a long interval of geologic time.

\section{CONCLUSIONS}

Variations in Steriberg's Law can be applied to sediments that were deposited under prograding conditions. Because currents move over beds that are characterized by a topographic gradient, the size decrease in the sediments is exponential in nature over given linear distances of transport (rivers in the Canadian Arctic Archipelago). In examining this phenomenon in beds of geologic antiquity, it was found that the semi-logarithmic, size-distance curves could be applied to successive units deposited under prograding conditions. This rule, expressed mathematically as $\mathrm{Y}=\mathrm{Y}_{\mathrm{O}} \mathrm{e}^{-\mathrm{ax}}$ (see text) was found to be operational over long periods of geologic time. For example, it applied for different parts of the same geological member (lower and upper Grimsby), as well as for two successive members (Grimsby and Thorold of the Silurian of the Niagara Peninsula); it held for a single"formation (Toad) as well as for successive formations (Toad, Liard, and Grey Beds of the Triassic of northeastern British Columbia); and it could be demonstrated for successive rock systems (Upper Devonian sandstones, the Mississippian Pocono Formation, and the Pennsylvanian Pottsville Conglomerate in the Central Appalachians).

In cases where Sternberg's Law functions throughout various intervals of geologic time, prograding conditions can be demonstrated. The representative grain size-distance curves for successive units (or successive parts of a unit) will form a family of curves of the same general expression: $\mathrm{Y}=\mathrm{Y}_{\odot e^{-\mathrm{ax}}}$. Divergence from parallelism of slopes within a given family of curves may reflect different tectonic conditions at the source area, for example, and hence a change in the gradient of the current bed.

Another factor relating to the phenomenon of exponential grain-size decrease with linear distance of transport is the intimate association of sedimentary anisotropy. This feature develops with a preferred direction of sediment growth regardless of the scale of the phenomenon. It can be deduced independently from the interpretation of the sizedistance curve $\left(Y=Y_{0} e^{-a x}\right)$, yet the latter is part of the phenomenon of anisotropy. But unless this size-distance curve is drawn parallel with the anisotropy trends of the accumulating body of sediment, a true relationship between it and sedimentary anisotropy cannot be inferred.

A variation of Sternberg's Law can be applied similarily with an analysis of the variation in crossbedding thickness in the Liard and overlying Grey Beds occurring in the Triassic formations of northeastern British columbia. The mean thickness of these units when plotted on a semi-logarithmic graph reveal the relationship of exponential decrease in thickness with linear distance along the paleocurrent direction. Prograding conditions are also indicated from an examination of the superposition of the Grey Beds' thickness-distance graph, over that of the Liard. Sedimentary anisotropy is also depicted because the cross-bedding decreases in thickness in the direction of sedimentary transport.

Additional indicators of sedimentary anisotropy may be utilized in order to support applications of Sternberg's Law that are based on various scalar properties of sediments. The following are examples: decreasing sand content, decreasing heavy mineral content, and changing proportions of clastic fractions such as the silt/clay ratio. Vectoral properties of sedimentary bodies may also be used to establish paleocurrent direction, paleoslope attitude, and sedimentary anisotropy. For example, directional indications may be determined at the outcrop by measuring the dip of foreset beds, the lee direction of asymmetrical current ripples, and the plunge direction of festoon beds. Also, grosser directional indications may be determined from examinations of isopleth maps of scalar quantities such as mean grain size of arenaceous beds, pebble-diameters of conglomerates, and thickness of cross-bedded units. Finally isopachous maps and regional stratigraphic maps may serve in the overall analysis of determining sedimentary anisotropy.

The exponential law of grain-size decrease with linear distance of sediment transport, and its relationship to sedimentary anisotropy and progradation operates from the geologically simplest temporal plane, through a time interval spanning several millions 
of years (perhaps $100 \mathrm{Ma}$ ). This is again observed in the graphs depicting the family of size-distance curves representing grain-size changes in a direction paralleling that of sedimentary anisotropy. The superposition of the younger beds over the older ones, as shown by the graphs, clearly indicates the occurrence of sedimentary anisotropy and prograding conditions. Thus, the sedimentologic continuum of Sternberg's Law, sedimentary anisotropy, and progradation operating throughout long intervals of geologic time is demonstrated.

\section{ACKNOWLEDGEMENTS}

I thank those many laboratory and field assistants who aided this study over the years. A great part of this body comprised students, who offered challenges with each question asked. In presenting this material to sedimentology classes, I have enjoyed many discussions with the students and their teachers. My own teachers - Thomas Clark at McGill University, Herbert Armstrong, formerly at McMaster University, and Frances Pettijohn at the Johns Hopkins University - led me into this fascinating field. One of my own former students, and later colleague, Grant Bartlett, prompted me to put some of these lecture ideas on paper as a special study for students. My former colleague, Peter Carr, reviewed the ideas presented here and was kind enough to offer many disciplined suggestions. To everyone, I express my thanks.

\section{REFERENCES}

BARRELL, J. 1925. Marine and terrestrial conglomerates; Geological Society of America, Bulletin 36 , pp. 279-342.

KNIGHT, R.J. 1977. Sediments, bedforms and hydraulics in a macrotidal environment, Cobequid Bay (Bay of Fundy), Nova Scotia; Ph.D. thesis, McMaster University, Hamilton, Canada, 429 pp.

LUMSDEN, D.N., and PELLETIER, B.R. 1969. Petrology of the Grimsby Sandstone (Lower Silurian) of Ontario and New York; Journal of Sedimentary Petrology, vol. 39, n. 2, pp. 521-530.

PELLETIER, B.R. 1958. Pocono Paleocurrents in in Pennsylvania and Maryland; Geological Society of America, Bulletin 69, pp. 1033-1064.

PELLETIER, B.R. 1962. Paleocurrents in the Triassic of northeastern British Columbia; in Primary Sedimentary Structures and their Hydrodynamic Interpretation; G.V. Middleton, ed., Society of Economic Paleontologists and Mineralogists, Special Publication 12, August 1965, pp. 223245 .

PELLETIER, B.R. 1963. The Grimsby Sandstone in the Niagara Peninsula; M.Sc. thesis, McMaster University, Hamilton, Canada, $122 \mathrm{pp}$.
PELLETIER, B:R. 1962. Paleocurrents in the Triassic of northeastern British Columbia; in Primary Sedimentary structures and their Hydrodynamic Interpretation; G.V. Middleton, ed., Society of Economic Paleontologists and Mineralogists, Special Publication 12, August 1965, pp. 223-245.

PELLETIER, B.R. 1963. The Grimsby Sandstone in the Niagara Peninsula; M.Sc. thesis, McMaster University, Hamilton, Canada, $122 \mathrm{pp}$.

PELLETIER, B.R. 1966. Development of submarine physiography in the Canadian Arctic and its relation to crustal movements; in Symposium on Continental Drift, ed., G.V. Garland, Roy Society of Canada, Special Publication 9, pp. 77-101.

PELleTIER, B.R. 1967. Sedimentation in Arctic waters of the western Queen Elizabeth Islands, District of Franklin, Canada; Maritime Sediments, vol. 3, n. 4 , pp. 90-99.

PELLETIER, B.R. 1975. Sediment dispersal in the southern Beaufort Sea; Environment Canada, Sidney, British Columbia, Beaufort Sea Technical Report 25a, 80 pp.

PELLETIER, B.R. 1979. Review of surficial geology and engineering hazards in the Canadian offshore; Maritime Sediments, v. 15, n. 2 and 3, pp. 55-91.

PETTIJOHN, F.J. 1975. Sedimentary rocks; Third Edition, Harper and Row, New York, 628 p.

PLUMLEY, W.J. 1948. Black Hills terrace gravels: A study in sediment transport; Journal of Geology, v. 56, pp. 526-577.

SCHLEE, J.S. 1956. The petrology of the upland gravels of southern Maryland and their origin; Ph.D. dissertation, The Johhs Hopkins University, Baltimore, Maryland, U.S.A.

SORBY, H.C. 1859. On the structures produced by the currents present during the deposition of stratified rocks; the Geologist, vol. 2, p. 137147.

STERNBERG, H. 1875. Untersuchungen über langen- und Querprofil geschiebeführende Flusse, $z$. Bauwessem 25, p. 483-506.

SWIFT, D.J.P., PELLETIER, B.R., LYALL, A.K. and MILLER, J.A. 1973. Quaternary sedimentation in the Bay of Fundy; in Earth Science Symposium on Offshore Eastern Canada, ed., P.J. Hood, Geolocial Survey of Canada, Paper 71-23, pp. 113-151.

YEAKEL, L.S., Jr. 1962. Tuscarora, Juniata, and Bald Eagle paleocurrents and paleogeography in the Central Appalachians; Geological Society of America, Bulletin 73, pp. 1515-1540. 


\section{APPENDIX}

Paleocurrent indicators in the Mid-Paleozoic of the Central Appalachians

(a) Planar cross-bedding in Pocono Formations. Foreset beds easily visible due to splitting along foreset planes, lying parallel to hanter. Tops are truncated, bottoms slightly tangential. Note uniform thickness of cross-bedded units bounded by essentially parallel planes (true bedding) which dip $70^{\circ}$ to left in photograph. Current direction from right (southeast).

(b) Ripple marks in Pocono Formation. Ripples are seen on underside of bedding. They are asymatric, have a wave length of 4 or 5 inches $(10-13 \mathrm{~cm})$, and indicate currents moved from left to right (southeast to northwest) in photograph.

(c) Pottsville Conglomerate - Pebbles are chiefly quartz and are exposed on bedding plane, and are similar in shape to pebbles in Pocono Formation.

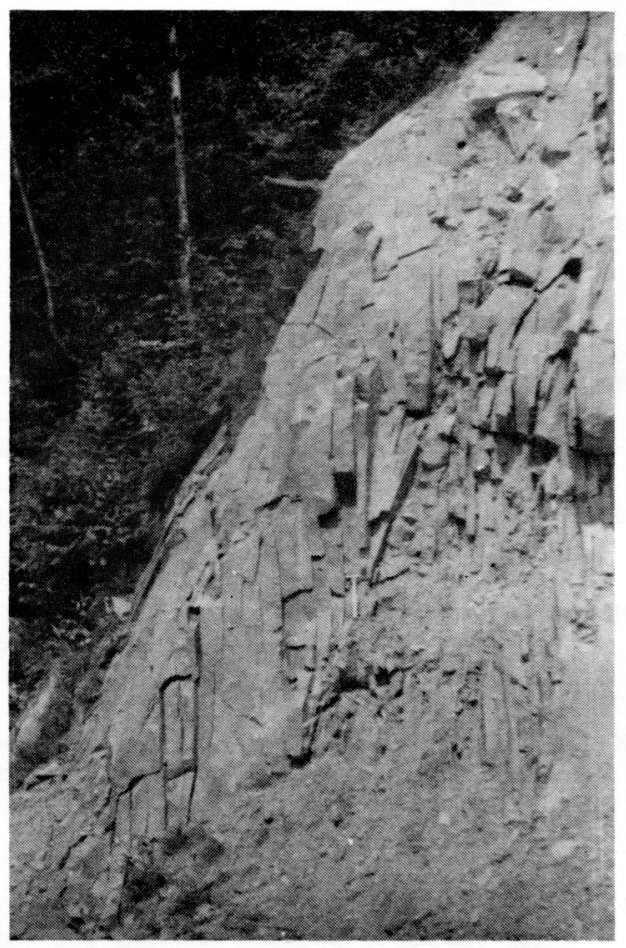

(a)

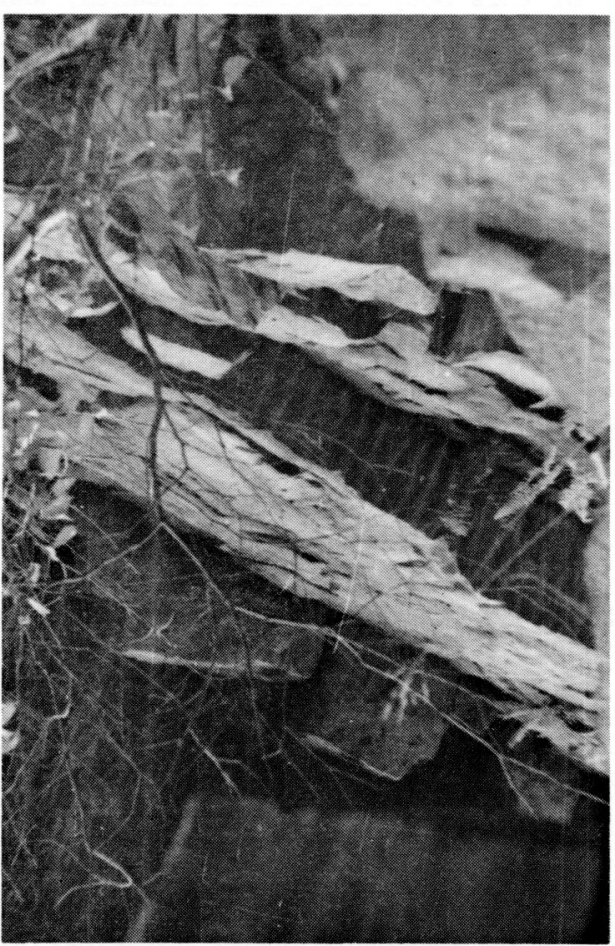

(b)

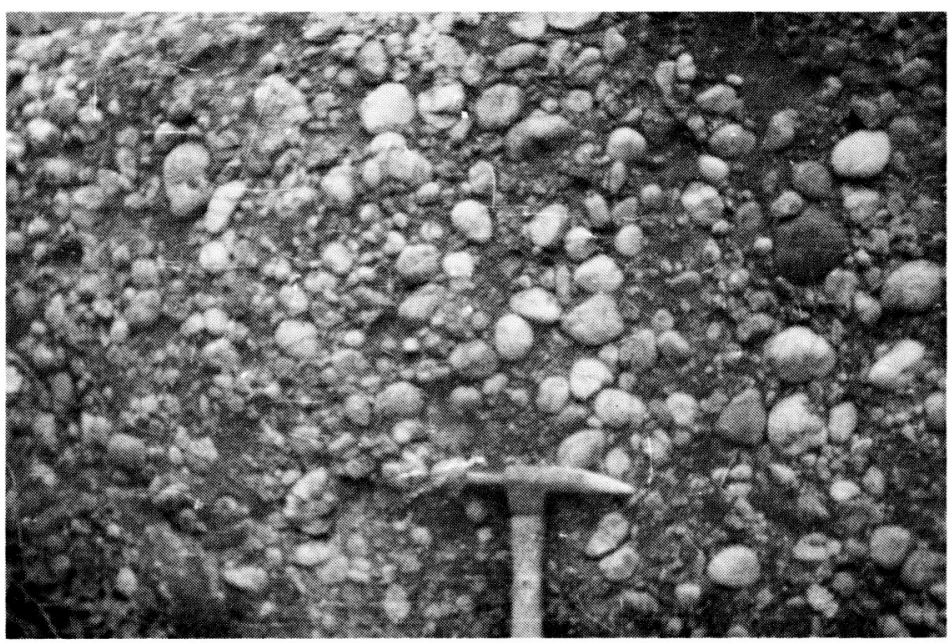

